\title{
Jesper Tynell
}

\section{Om forholdet mellem sprog $0 \mathrm{~g}$ magt i statsadministrationen}

Sproglige spidsfindigheder spiller en central rolle, når danske embedsmoend skorer tal, jura og faktuelle oplysninger til, så de bedst muligt understøtter regeringens politik udadtil. Det fremgår af bogen 'Mørkelygten', der bygger på emails, notater og op mod hundrede samtaler med embedsmond om konkrete sager, hvor Folketinget og befolkningen er blevet prosenteret for mere eller mindre vildledende oplysninger. Men også embedsvarkets interne sprogbrug vidner om en vis normalitet $i$ denne praksis.

Må embedsmænd handle ulovligt eller skrive usandt, hvis de får besked på at gøre det? Det kommer måske bag på de fleste, at svaret er ja. Når det med jævne mellemrum også sker i praksis, lever de involverede embedsmænd så op til deres pligter som embedsmænd? Igen er svaret tilsyneladende ja.

I størstedelen af de sager, jeg har undersøgt og gennemgår i min bog Mørkelygten ${ }^{29}$, lever de involverede embedsmænd i vid udstrækning op til de forpligtelser, der følger af deres arbejde. Dette gælder selv i en del af de sager, der i den offentlige debat bliver betragtet som odiøse eller ligefrem skandaløse. Det skyldes blandt andet, at embedsmænd, som reglerne er i dag, har en ganske vidtgående pligt til at adlyde deres overordnede og kan straffes for ikke at gøre det - selv hvis de er i tvivl, om det er ulovligt, hvad de gør, eller usandt, hvad de skriver.

Et andet væsentligt spørgsmål er derfor, om ansvaret kan føres op gennem systemet igen, når embedsmænd handler ulovligt eller giver urigtige eller vildledende oplysnin-

29 Tynell, Jesper (2014): Mørkelygten - embedsmænd fortæller om politisk tilskæring af tal, jura og fakta, Samfundslitteratur, København 
ger til Folketing og medier? Her er svaret til gengæld ofte nej. Selv om de nuværende regler giver embedsmændenes overordnede vide muligheder for at få gennemført selv ulovlige handlinger eller fremlagt vildledende oplysninger for de folkevalgte og vælgerne, så er reglerne samtidig indrettet på en måde, der ofte gør det vanskeligt at stille de samme overordnede juridisk til ansvar. Topembedsmænd og ministre kan altså her befinde sig i den behagelige situation, at de har maksimal indflydelse, samtidig med at risikoen for at blive stillet juridisk til ansvar for deres dispositioner er minimal.

I sidste ende er spørgsmålet derfor, hvad de nuværende regler for embedsmænd betyder for Folketingets indflydelse og den demokratiske forankring af de politiske beslutninger? Hvad betyder de for det, vi normalt kalder den parlamentariske styringskæde?

$[\ldots]$

\section{Så længe det blot er ulovligt}

Det er en udbredt misforståelse, at regeringens embedsmænd har pligt til neutralt at følge lovgivningen og levere sandfærdig og fyldestgørende viden og oplysninger til folketing, medier og befolkning. Forestillingen om den politisk upåvirkede embedsmand finder for eksempel næring i betænkning 1443 om embedsmænds rådgivning og bistand. Heri understreges det flere gange, at embedsmænd i deres arbejde er underlagt krav om "lovlighed, sandhed, faglighed og partipolitisk neutralitet" (Betænkning 1443).

Hvad betænkningen derimod ikke nævner er, at andre spilleregler har forrang herfor. Embedsmænds lydighedspligt trumfer og kan tilsidesætte disse normer. Hvis embedsmandens overordnede insisterer på at få gennemført noget, der nok kan siges at være ulovligt, men ikke er klart ulovligt, eller insisterer på at udbrede usande oplysninger, der dog ikke med sikkerhed kan siges at være klart usande, så har embedsmanden ikke pligt til at sætte hælene i og sige fra. Det fremgår af den juridiske litteratur på området. Tidligere juraprofessor og nu højesteretsdommer Jens Peter Christensen skriver for eksempel.:

I tilfælde, hvor ordren ikke kan siges at være klart ulovlig, men hvor der dog kan argumenteres på lødig og vægtig måde for, at der foreligger ulovlighed, har det været den almindelige opfattelse i teorien, at hensynet til den overordnedes bestemmelsesret må have overvægt i forhold til kravet om lovmæssig forvaltning, således at embedsmanden har både ret og pligt til at efterkomme ordren. ${ }^{30}$ 
Embedsmanden må altså gerne handle ulovligt, hvis han først har advaret sin overordnede herom, og den overordnede alligevel beder ham eller hende om at gøre det. Så længe en ordre "blot" er ulovlig, men ikke er "klart" ulovlig, har embedsmanden ikke pligt til at sige fra og undlade at udføre den.

Tværtimod kan en embedsmand i visse situationer straffes med op til 4 måneders fængsel, hvis han eller hun vægrer sig og underlader at adlyde, også selvom han er i tvivl om lovligheden heraf. Siden starten af 90erne har man diskuteret, om man så også i praksis vil straffe den embedsmand, der modsætter sig en ordre om at gøre noget, der "blot" er ulovligt, men ikke er "klart" ulovligt. Selvom en embedsmand her forventes at kunne skelne mellem ulovligt og klart ulovligt, kan vedkommende under alle omstændigheder slippe for straf for at tilsidesætte lydighedspligten, hvis det efterfølgende viser sig, at han har haft svært ved at se forskel på de to. Det fremgår blandt andet af betænkning 1472 om offentligt ansattes ytringsfrihed, som Jens Peter Christensen også har stået spidsen for:

Det antages (...) at den ansatte i praksis vil blive givet en fejlmargin, når det gælder vedkommendes vurdering af, om en ordre var ulovlig eller klart ulovlig. Hvis (...) vedkommende fejlagtigt vurderede ordren som klart ulovlig (og ikke "blot" ulovlig), vil der således ikke være anledning til at gøre ansvar gældende for tilsidesættelse af lydighedspligten. ${ }^{31}$

Så længe en ordre blot er ulovlig, har embedsmanden altså under ingen omstændigheder pligt til at sige fra, men kan udføre opgaven og gøre det helt inden for de regler, der i dag gælder for embedsmænds arbejde. Det samme gælder for klart ulovlige ordrer, hvis embedsmanden i situationen tror, at ordren blot er ulovlig.

Bliver en embedsmand bedt om at give usande oplysninger til Folketinget, medierne eller vælgerne, er spillereglerne de samme. Teknisk set udgør forholdet til sandheden blot en underafdeling af reglerne vedrørende ulovlige handlinger. Selvom embedsmanden også her kan have ret til at sige fra, så har han ikke pligt til at gøre det, så længe oplysninger "blot" er usande eller "blot" er vildledende:

I tilfælde, hvor det ikke er helt klart, om ministerens oplysninger er urigtige eller vildledende m.v., men hvor der dog er en stærk begrundelse for at mene, at dette er tilfældet, må det tilsvarende antages, at embedsmanden har ret (men ikke pligt) til at 'sige fra.' ${ }^{32}$

31 Betænkning 1472, s. 107-108 (mine fremhævelser)

Christensen (2002), s. 325 (min fremhævelse) 
Når det gælder kravet om faglighed, kan der ofte være så forskelligartede faglige syn på en sag, at de oplysninger embedsværket lægger offentligt frem nok må siges at krænke deres faglighed, men alligevel vanskeligt lader sig betegne som klart ufaglige. Måske derfor beskæftiger den juridiske litteratur om spillereglerne for embedsmænd sig stort set ikke med grænsen mellem ufagligt og klart ufagligt. I en betænkning fra 1993 gør et udvalg nedsat af fagforeningen Djøf dog klart, at der er ganske vide grænser for, hvad embedsmænd må udføre af bevidst, faglig manipulation og "'misbrug' af fagkundskab":

Et bevidst forvansket økonomisk skøn over udgifter og indtægter ved et offentligt anlægsarbejde er selvsagt forkasteligt [sic] ud fra såvel politiske som fagøkonomiske og etiske synspunkter, men det vil sjældent blive stemplet som retsstridigt i sig selv. ${ }^{33}$

Hvis det er umuligt at få politisk opbakning til at bygge en ny bro, der ifølge embedsværkets beregninger vil koste 10 mia. kroner, behøver der altså ikke nødvendigvis være noget til hinder for, at embedsværket i stedet bevidst fremlægger et manipuleret og fagligt ukorrekt budget, der sætter prisen til 5 mia. kroner, for at vinde politisk opbakning til forslaget. Selvom embedsmændenes overordnede helt overlagt går efter at få byggeprojektet vedtaget på et misvisende grundlag, vil embedsmænd altså sjældent have pligt til at sige fra og undlade at medvirke til et sådant bedrag. Da embedsmænd samtidig kan straffes, hvis de ikke gør, hvad de får besked på, vil de derfor i mange situationer blot gøre deres arbejde og udføre det, der altså må siges at følge med jobbet.

\section{Inden for rammerne}

Når det med jævne mellemrum kommer offentligt frem, at embedsmænd har handlet ulovligt eller leveret usande eller misvisende oplysninger til Folketinget og vælgerne, behøver det altså ikke at være i strid med de pligter, de er pålagt som embedsmænd. De 12 sager, jeg har undersøgt og analyseret under mit fellowship ved Institut for Statskundskab på Syddansk Universitet, vidner tværtimod om, at embedsværket i vid udstrækning lever op til sine nu værende pligter . I min undersøgelse af embedsværkets ageren, som jeg redegør for i bogen Mørkelygten ${ }^{34}$, kan man således iagttage en række gennemgående træk at regne baglæns: Hvis embedsmændene får besked på at gøre det, regner de med egne ord baglæns i den forstand, at de offentligt fremlægger tal, jura og fakta, der understøtter regeringens politiske ønsker. Hermed lever de i vid udstrækning op til den lydighedspligt, de er underlagt. "Resultatet er givet på forhånd,

Tynell (2014), op. Cit. 
før man begynder at lave analysen", som en embedsmand f.eks. forklarer i bogens kapitel 1, der handler om en skriftlig besked, han og hans kolleger modtager, om at skrive et notat med et på forhånd bestemt resultat, der skal plantes i pressen og bruges i de politiske forhandlinger.

1. En tilstrækkelig klar advarsel: Når embedsværket kommer på kant med lovgivningen eller sandheden, fremgår det af en række af sagerne, at de involverede embedsmænd tillige lever op til deres forpligtelse til på forhånd at advare deres overordnede herom på de indre linjer. Hvis deres overordnede alligevel fastholder ønsket, bliver disse advarsler i reglen ikke givet videre til Folketinget eller vælgerne, hvorved embedsværket tilsyneladende også lever op til sin loyalitetsforpligtelse. "Det, som er sivet til artiklen i Politiken i dag, er vel det, som skal sive, men jeg vil gerne være sikker på, at ministrene er klar over, at den juridiske vurdering reelt er noget anderledes", som en embedsmand i Udenrigsministeriet for eksempel skriver i et brev til Statsministeriet vedørende. en sag, hvor embedsmændene udadtil blåstempler en afgift rent juridisk, mens de gentagne gange advarer indadtil om, at afgiften udgør ulovlig statsstøtte.

2. Halmstrå og figenblade: De argumenter, som embedsværket efter anmodning opbygger til brug over for offentligheden, omtaler flere embedsmænd ifølge e-mails og udsagn selv som "halmstrå" og "figenblade". I den forbindelse synes det også i praksis at være et gennemgående pejlemærke, at argumentationen nok kan dække over ulovligheden eller bygge på usandheder, men ikke må dække over noget klart ulovligt eller indeholde isoleret set klart usande oplysninger. Selv meget kreative fortolkninger af lovgivning og sandhed bliver i praksis brugt til udadtil at gøre gældende, at noget er lovligt eller sandt - også selvom embedsværket på de indre linjer opfatter det som ulovligt eller usandt, dog uden at være klart ulovligt eller klart usandt. "Vi er advokater, der medvirker til at hjælpe regeringen til at nå det resultat, den gerne vil, på et område, hvor man ikke kan sige, at det er klart ulovligt", som en embedsmand pointerer.

3. At forklæde politik som teknik: Hvis embedsværket får besked på det, medvirker det således på forskellig vis til fagligt at bane vej for og legitimere, hvad der i realiteten er politisk begrundede beslutninger. Ministre gør sig således i flere sager anstrengelser for udadtil at fremstille embedsværkets notater og rapporter som neutrale og udtryk for en uhildet sagkundskab, selvom de involverede embedsmænd i realiteten er underlagt politisk ledelse og handler herefter. I kølvandet på bogens udgivelse er der fremkommet flere yderligere eksempler på dette. En tidligere udenrigsminister har for eksempel i en tv-debat foranlediget af bogen givet indtryk af, at hans embedsmænd havde "fuld uafhængig- 
hed" i deres juridiske vurderinger i forbindelse med beslutningen om at gå i krig i Irak i 2003. Og en justitsminister har ligeledes i forbindelse med Eritreasagen flere gange over for Folketinget betegnet en af sine egne styrelser som "en uafhængig myndighed". Dette altså, selvom embedsmændene i begge tilfælde er underlagt ministrenes instruktionsbeføjelser og derfor i vid udstrækning har pligt til at gøre, hvad de får besked på.

De normer, som embedsmændene i praksis agerer efter i deres arbejde, flugter således udmærket med de regler og pligter, som embedsmænd i dag er underlagt. Når en række betænkninger om embedsmænds rådgivning og bistand i væsentlighed blot gentager de underordnede krav om "lovlighed, sandhed, faglighed og partipolitisk neutralitet", indgyder de derimod offentligheden en fejlagtig forestilling om, at notater, rapporter og redegørelser fra centraladministrationen kan betragtes som politisk upåvirkede. En forestilling, der er afgørende for, at en stor del af den politiske magtudøvelse udadtil fremstår som apolitisk saglighed og derfor bliver vanskeligere at kritisere.

Når visse topembedsmænd og undervisere på universitetet betegner "lovlighed, sandhed, faglighed og partipolitisk neutralitet" som "embedsmandsdyder" og mener, at "embedsmandsetikken" er under pres, bærer de desværre ved til samme bål. Det samme gælder dem, der påpeger, at det må skyldes manglende kendskab til kravene om "lovlighed, sandhed, faglighed og partipolitisk neutralitet", når embedsmænd i praksis handler ulovligt eller lægger vildledende oplysninger offentligt frem. I virkeligheden har langt de fleste embedsmænd en høj etik og moral og kender udmærket godt de højt besungne idealer om "lovlighed, sandhed, faglighed og partipolitisk neutralitet". Men de ved samtidig, at hvis de skal holde sig på dydens smalle sti og overholde reglerne for embedsmænd, så skal de først og fremmest levere, hvad de får besked på, så længe det "blot" er ulovligt eller usandt, men ikke er "klart" ulovligt eller "klart" usandt. "Hvis ikke du gør det, så kan du ikke bruges. Så hører du til på universitetet", som en embedsmand fortæller.

\section{Problemer med den parlamentariske styringskæde}

Selvom der i teorien kan være udemærkede grunde til, at systemet er indrettet, som det er, synes den bagvedliggende argumentation alligevel at være baseret på flere logiske brist.

Den vidtgående lydighedspligt er bl.a. begrundet med, at ministeren har et demokratisk mandat, som embedsmændene ikke har. Det er imidlertid langt fra givet, at ministeren har et demokratisk mandat i et land, hvor mindretalsregeringer er mere reglen end undtagelsen. Et demokratisk mandat er derimod noget, ministeren løbende skal arbejde for at skaffe sig fra et flertal i Folketinget. Eksemplerne i bogen viser i den forbindelse, at den vidtgående lydighedspligt ikke nødvendigvis bruges til at udmønte, 
men derimod til at opnå et (falsk) demokratisk mandat. I det omfang, at Folketing og vælgere havde ageret anderledes, hvis de havde haft indsigt i det fulde faglige grundlag og de advarsler, embedsværket kun leverer internt til regeringen, kortslutter de nuværende regler for embedsmænd altså i praksis den demokratiske beslutningsproces. Det samme gør sig gældende i de situationer, hvor et flertal i Folketinget har vedtaget en lovgivning, som embedsmænd får besked af deres overordnede på ikke at overholde al den stund, det "blot" er ulovligt, men ikke "klart" ulovligt.

En anden begrundelse for den vidtgående lydighedspligt er, at den samler indflydelse og ansvar på ét og samme sted: Hos ministeren. I praksis følges indflydelse og ansvar dog langt fra altid ad. I bogen gennemgår jeg en lang række forhold, der reelt gør det vanskeligt at føre ansvaret for forsætligt at krænke lovgivningen eller sandheden op gennem systemet igen, når først en topembedsmand eller minister har sat sin indflydelse igennem fra top til bund. Det gælder bl.a. det såkaldte forsigtighedsprincip og princippet om, at uegentlige retsvildfarelser diskulperer, som det hedder. ${ }^{35}$ For her blot at nævne et mere enkelt forhold, der kan få ansvaret til at forsvinde, så eksisterer der i dag ikke et formkrav til ordrer om at agere på kant med lovgivningen eller overskride sandheden. En venlig anmodning kan efter omstændighederne betragtes som en ordre. Den underordnede kan derfor i praksis pege på en e-mail eller anden besked og henholde sig til, at han eller hun blot har handlet efter ordre og derfor er ansvarsfri. Den overordnede kan imidlertid samtidig afvise, at den samme e-mail er udstedt som en egentlig ordre, at vedkommende derimod blot har spurgt venligt, om noget kan lade sig gøre, og derved også erklære sig fri for ansvar. Det er altså blot ét af flere forhold ved det nuværende system, der i realiteten skaber et ansvarsvakuum, der gør, at indflydelse og ansvar ikke nødvendigvis følges ad. Den overordnede har i realiteten ganske stor indflydelse, men slipper samtidig let for at blive draget til ansvar.

Et tredje argument for den vidtgående lydighedspligt er, at systemet skal sikre, at ministeren bestemmer og forhindre embedsmandsvælde. Men den vidtgående lydighedspligt gælder ikke alene mellem ministre og embedsværk. Den gælder også ordrer og anmodninger udstedt af enhver anden overordnet. Den fuldmægtige skal adlyde sin kontorchef, kontorchefen skal adlyde sin afdelingschef, og afdelingschefen skal adlyde sin departementschef. Derfor kan også topembedsmænd bruge lydighedspligten til at sætte deres viljer igennem overfor underordnede helt ud i de statslige styrelser. Det privilegium er ikke forbeholdt ministre.

I de 12 sager, jeg har undersøgt, ved de fleste embedsmænd således ikke med sikkerhed, om de ordrer de modtager oppefra kommer fra ministeren eller blot stammer fra ministeriets departementschef eller øvrige ledelse. Begrundelsen for den vidtgående lydighedspligt hviler altså også på en forkert antagelse om, at den sikrer, at det 
altid er ministeren, der bestemmer. I realiteten muliggør spillereglerne i ligeså høj grad topembedsmandsvælde. Et fjerde argument bag den vidtgående danske lydighedspligt er, at embedsmænd ved, hvad de har at rette sig efter. Hovedreglen er den enkle, at de gør det rigtige, hvis de følger de ordrer og anmodninger, de modtager, mens de gør det forkerte, hvis de vægrer sig. I praksis forholder det sig imidlertid anderledes. Kommer der en møgsag, og bliver medierne tilstrækkeligt hysteriske, og mener Folketinget også, at der skal rulle hoveder, bliver resultatet ikke sjældent, at man ofrer en embedsmand et sted i systemet ved f.eks. at flytte en chef fra én chefstilling til en anden. Helt uden juridisk proces og retssikkerhed anvender man den diskretionære ledelsesret til demonstrativt at forflytte enkelte embedsmænd, selvom de formentlig sjældent har handlet alene og muligvis blot har været med til at udføre det arbejde, de forventes og i vid udstrækning har pligt til at udføre. Når den vidtgående lydighedspligt reelt gør det vanskeligt at overskride grænserne rent juridisk, bliver resultatet derfor med jævne mellemrum i praksis, at embedsmænd må tåle den vilkårlighed, det kan være at blive udvalgt til offentligt at påtage ansvaret for en sag, som de ikke nødvendigvis er ansvarlige for.

På den måde viser sagerne i bogen samlet set, at der er langt mellem teori og praksis. Mens reglerne i teorien siges at understøtte en demokratisk forankring af den politiske beslutningsproces, er de i praksis medvirkende til, at den parlamentariske styringskæde med jævne mellemrum knækker. Her er de nuværende regler altså mere befordrende for ministerielt topstyre end for folkestyre.

De nuværende regler synes da også at bero på en forestilling om, at stærk topledelse - snarere end lovgivning vedtaget af et oplyst Folketing - gør den statslige forvaltning mere effektiv. Det fremgår bl.a. af betænkning 1472 om embedsmænds ytringsfrihed:

I hvilket omfang embedsmænd har ret og pligt til at "sige fra" over for ulovlige ordrer kan grundlæg-gende beskrives som et spørgsmål om afvejningen af hensynet til forvaltningens effektivitet eller ledelsens bestemmelsesret over for kravet om lovmæssig forvaltning. ${ }^{36}$

I min undersøgelse af 12 sager forankret i Beskæftigelsesministeriet, Justitsministeriet, Udenrigsministeriet, Integrationsministeriet, Socialministeriet og Finansministeriet er det imidlertid vanskeligt at se, at den vidtgående lydighedspligt i praksis sikrer en effektiv forvaltning. Flere sager viser tværtimod, at det modsatte er tilfældet.Og selvom de nuværende regler for embedsmænd i sidste ende beror på en overordnet politisk beslutning om, hvilken styreform man ønsker at fremme, så har Folketinget aldrig være involveret i denne beslutning. De nuværende regler hviler alene på den

36 Betænkning 1472, s. 106 (mine fremhævelser) 
juridiske litteratur, på praksis fra skiftende undersøgelsesorganer og på betænkninger fra centraladministrationen selv. Selvom flere regeringer ved Folketingets åbning har annonceret i deres lovprogrammer, at de ville fremsætte lovforslag vedr. grænserne for embedsmænds lydighedspligt, så er disse lovforslag aldrig efterfølgende blevet fremsat over for tingets medlemmer. Som Jens Peter Christensen beretter:

Synspunktet blandt centraladministrationens topfolk skulle angiveligt have været, at det ikke er godt med for mange regler på dette område.

Folketinget har derfor aldrig fået lejlighed til at tage stilling til de helt grundlæggende politiske valg, som reglerne for embedsmænd afspejler. Valg, der i sidste ende beror på en afvejning af Folkestyre over for et mere administrativt topstyre.

\section{Summary}

Linguistic hair-splitting plays a central role when Danish officials carve up figures and legal and factual information in ways that best suit the Government's public policy. This emerges from the book 'Mørkelygten' ('The Dark Light'), which is based on emails, notes and almost a hundred conversations with officials on specific matters where Parliament and the public have been presented with more or less misleading information. But the use of language within the civil service also bears witness to a certain normality in this practice.

Denne artikel har veret optrykt i Futuriblerne, september 2015, årgang 43. nr. 2-3.

\section{Bibliografiske oplysninger}

Tynell, Jesper, 2016: Om forholdet mellem sprog og magt i statsadministrationen. I: Fra myndig maktspråk til klar kommunikasjon - Rapport fra Nordisk klarspråkskonferanse Oslo 28.-29. mai 2015, 107-115.

http://ojs.statsbiblioteket.dk/index.php/ksn

(C) Författarna och Nätverket för språknämnderna i Norden 
